\title{
REPRODUCTIVE PERFORMANCE OF SOWS ON A PROTEIN-RESTRICTED DIET*
}

\author{
A. J. SVAJGR, D. L. HAMMELL, M. J. DEGEETER, V. W. HAYS, \\ G. L. GROMWELL AND R. H. DUTT \\ Department of Animal Sciences, University of Kentucky, \\ Lexington, Kentucky 40506, U.S.A.
}

(Received 24th December 1971, accepted 25th March 1972)

\begin{abstract}
Summary. Two trials with sixty-five sows indicate that severe protein restriction during gestation and lactation significantly impairs subsequent reproductive efficiency. The percentage of sows exhibiting oestrus, the average number of days from weaning to oestrus, and the average ovulation rate and uterine weights were significantly lower in sows fed a low-protein diet. Conception rate and embryo survival to 28 days were not significantly affected. The detrimental effects from protein restriction were more severe in younger gilts. Oestrus, ovulation and fertility were induced in non-cyclic sows fed the low-protein diet by injecting PMSG and HCG.
\end{abstract}

Varying the dietary protein intake of gilts and sows during gestation has resulted in small differences in the litter size and birth weight of pigs. Lucas, Speer \& Hays (1966), Frobish, Speer \& Hays (1966), Pond, Strachen, Sinka, Walker, Dunn \& Barnes (1969), Holden, Lucas, Speer \& Hays (1968), Baker, Becker, Jensen \& Harmon (1970), DeGeeter, Hays, Kratzer \& Cromwell (1970) and DeGeeter, Hays, Cromwell \& Kratzer (1970) found little difference in the reproductive performance of gilts and sows fed crude protein levels ranging from 9 to $364 \mathrm{~g} /$ day throughout gestation. Boaz (1962) found a tendency towards irregular return to oestrus and a longer interval from weaning to conception in sows fed $280 \mathrm{~g}$ as compared with $493 \mathrm{~g}$ crude protein/day for three reproductive cycles. Adams, Becker, Terrill, Norton \& Jensen (1960) reported that puberal gilts fed a protein-free diet failed to cycle normally or to conceive.

The reproductive performance of two groups of sows following one gestation and lactation period on a low- or high-protein diet as gilts is reported here. The reproductive performance of the females as gilts and the effects of protein level during gestation on the growth rate of the pigs have previously been reported by DeGeeter, Hays, Kratzer \& Cromwell (1970) and DeGeeter, Hays, Cromwell \& Kratzer (1970). Their analysis showed no significant effect of protein level on the percentage of gilts farrowing, the litter size or the birth weight of pigs. Subsequent reproductive performance is presented for those gilts which weaned litters.

In the first trial, crossbred gilts, averaging $153 \mathrm{~kg}$ body weight and 15 months

* Published with approval of the Director of the University of Kentucky Agricultural Experiment Station as Journal Article 71-5-136. 
of age, were allotted to a $2 \%$ (low) or a $17 \%$ (high) protein diet 15 days after mating. Corn contributed all of the protein in the low-protein diet with dextrose added to reduce the protein level to $2 \%$. The sows were individually fed at a rate of $1.82 \mathrm{~kg} /$ day until parturition, at which time the protein level of the $2 \%$ protein diet was raised to $5 \%$, with both diets fully fed for a 14-day lactation period. Sows from which litters were weaned were housed in groups in openfronted, concrete-floored pens and were individually fed $2 \cdot 27 \mathrm{~kg} /$ day of diets containing the same protein levels as those fed during lactation.

All sows were checked daily for oestrus using teaser boars and were mated by natural service. Pregnant sows were slaughtered 28 days after mating and their reproductive tracts examined. Sows returning to oestrus after mating were slaughtered on the day of oestrus and the number of regressing corpora lutea was recorded. Sows not exhibiting oestrus within 35 days of weaning were slaughtered and their reproductive tracts were examined. Histological sections were prepared from the uteri for comparison with sections of uteri from high protein sows slaughtered on the day of oestrus.

In Trial 2, the same procedures were used as in Trial 1 except that the gilts averaged $120 \mathrm{~kg}$ body weight and 9 months of age, when they were allotted to the two protein levels 15 days after mating. Since none of the sixteen gilts fed the low-protein diet in this trial cycled within 35 days of weaning, eight were slaughtered and the remaining eight were injected subcutaneously with 1500 i.u. PMSG followed $90 \mathrm{hr}$ later with an intramuscular injection of 750 i.u. HCG. These sows were slaughtered 6 days after the HCG injections. The data were tested for significance by analysis of variance or chi-square.

The reproductive performance of the gilts after weaning a litter is presented in Table 1. In Trial 1, all sows fed the high-protein level exhibited oestrus from 1 to 7 days of weaning, with a mean of 4.5 days. Only ten of the eighteen sows fed the low level of protein exhibited oestrus within 35 days of weaning with a range of 6 to 13 days and a mean of 9.5 days. The number of sows exhibiting oestrus and the average number of days from weaning to oestrus for sows that cycled were significantly $(P<0.005)$ different for the two protein levels. In sows that did cycle, the low-protein level did not significantly affect the conception rate or the number of embryos at 28 days of gestation. The average ovulation rate, as determined by the number of corpora lutea at slaughter, was significantly $(P<0.005)$ reduced in the sows fed the low-protein diet. There is no obvious explanation for the low conception rate in sows on the high-protein diet. Reproductive tracts (Pl. 1, Fig. 1) of the sows on the low protein level that did not exhibit oestrus were smaller and paler in colour than tracts from sows showing oestrus on the low- and high-protein diets. Ovaries from these sows contained only small follicles and had no corpora lutea.

The results of Trial 2 are also presented in Table 1. Twelve of the fourteen sows fed the high-protein level exhibited oestrus, whereas none of the sows fed the low-protein diet exhibited oestrus within 35 days of weaning. The difference in the frequency of oestrus in sows fed the low-protein level in the two trials probably resulted from the difference in age of the gilts at the start of the study ( 15 months in Trial 1 versus 9 months in Trial 2). The average weights at the end of lactation for high- and low-protein gilts in Trials 1 and 2 were 150 
PI.A'TI I

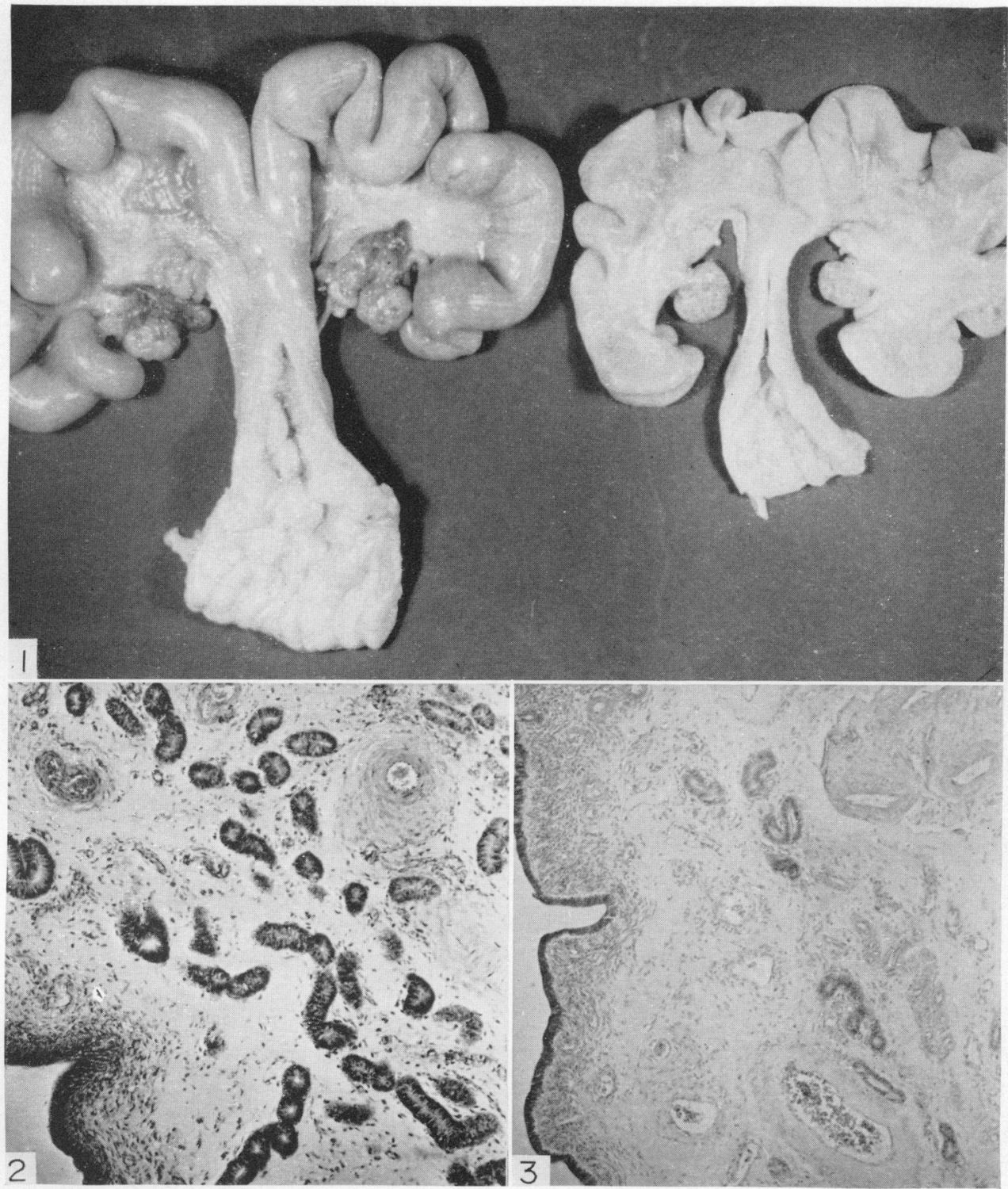

lici. 1. Lteri from a sow fed the high-protein diet (left) and from a non-creling sow fed the low-protein dice (right).

Fin. 2. Litrine section from a sow in ocstrus fed the high-protein diet $(\times 25)$.

Fic. 3. Literine section from an uninjected sow (Trial 2) fed the low-protein diet $(\times 25)$. Note presence of fewcr and smaller glands in comparison with the section from a sow fed the high-protein diet. 
and $135 \mathrm{~kg}$ versus 149 and $97 \mathrm{~kg}$, respectively. The detrimental effects of restricted protein intake on reproductive performance were more severe in the younger, lighter-weight sows.

The eight sows injected with gonadotrophins exhibited standing oestrus 12 to $36 \mathrm{hr}$ after the HCG injection. Three were mated $24 \mathrm{hr}$ after HCG administration and fertilized eggs were flushed from their uteri. Ovulation occurred in all of the injected sows, with a range of three to twenty-seven corpora lutea and an average of fifteen. The reproductive tracts of the injected sows responded to PMSG and HCG, resulting in a significant $(P<0.001)$ increase in uterine weight

TABLE 1

REPRODUCTIVE PERFORMANCE OF SOWS FOLLOWING A GESTATION-LACTATION ON A HIGH- OR LOW-PROTEIN DIET ${ }^{\mathrm{a}}$

\begin{tabular}{|c|c|c|c|c|c|}
\hline \multirow{3}{*}{ Item } & \multicolumn{2}{|c|}{ Trial 1} & \multicolumn{3}{|c|}{ Trial 2} \\
\hline & \multicolumn{2}{|c|}{ Protein level $(\%)$} & \multicolumn{3}{|c|}{ Protein level $(\%)$} \\
\hline & 17 & 5 & 17 & 5 & $\begin{array}{l}P M S+ \\
H C G^{\mathbf{b}}\end{array}$ \\
\hline No. of sows & 17 & 18 & 14 & 8 & 8 \\
\hline $\begin{array}{l}\text { Sows exhibiting oestrus within } 35 \text { days after } \\
\text { weaning }{ }^{\mathrm{c}}\end{array}$ & $17(100)^{\prime}$ & $10(56)$ & $12(86)^{\mathrm{f}}$ & 0 & 0 \\
\hline $\begin{array}{l}\text { Average interval, weaning to oestrus (days) } \\
\text { Mean } \\
\text { S.D. }\end{array}$ & $\begin{array}{l}4.5^{2} \\
0.62\end{array}$ & $\begin{array}{l}9 \cdot 5 \\
0 \cdot 72\end{array}$ & $\begin{array}{l}5 \cdot 2^{8} \\
0.97\end{array}$ & - & 一 \\
\hline Sows pregnant, 28 days $^{c}$ & $7 \quad(41)$ & $6(33)$ & $11(79)$ & - & - \\
\hline $\begin{array}{l}\text { Average ovulation rated } \\
\text { Mean } \\
\text { S.D. }\end{array}$ & $\begin{array}{r}21 \cdot 8^{\mathrm{r}} \\
0.97\end{array}$ & $\begin{array}{c}16.9 \\
1.02\end{array}$ & $\begin{array}{r}13 \cdot 6^{\mathbf{w}} \\
0.59\end{array}$ & 0 & $\begin{array}{c}15.0 \\
3.09\end{array}$ \\
\hline $\begin{array}{l}\text { Average no. of live embryos, } 28 \text { days } \\
\text { Mean } \\
\text { S.D. }\end{array}$ & $\begin{array}{c}11 \cdot 1 \\
1 \cdot 20\end{array}$ & $\begin{array}{c}11.2 \\
1.83\end{array}$ & $\begin{array}{l}8 \cdot 25 \\
0 \cdot 77\end{array}$ & - & - \\
\hline Embryos/corpora lutea, 28 days $(\%)^{e}$ & $54 \cdot 5$ & $59 \cdot 8$ & $66 \cdot 4$ & - & - \\
\hline $\begin{array}{l}\text { Average uterine weight }(\mathrm{g}) \\
\text { Mean } \\
\text { S.D. }\end{array}$ & - & - & - & $\begin{array}{c}158 \\
4 \cdot 7\end{array}$ & $\begin{array}{c}435^{1} \\
32 \cdot 0\end{array}$ \\
\hline
\end{tabular}

- Isocaloric diets calculated to provide $17 \%$ (high) and $5 \%$ (low) crude protein.

- Sows injected 35 days after weaning with 1500 i.u. PMSG and 750 i.u. HCG.

- Figures in parentheses are percentages.

d Includes all sows.

- Includes pregnant sows only.

' Significant $(P<0.005)$ difference between protein levels.

2 Significant $(P<0.001)$ difference between protein levels.

h Significantly $(P<0.01)$ less than high-protein group in Trial 1.

' Significantly $(P<0.001)$ heavier than in uninjected sows.

(435 versus $158 \mathrm{~g}$ ). Seven of the eight injected sows also exhibited anovulatory and/or cystic follicles. The sows fed the high-protein diets in Trial 2 produced an average of 13.6 ova and had no cystic follicles.

Uterine histological sections from sows fed high-protein diets and uninjected sows fed the low-protein diet are shown in Pl. 1, Figs 2 and 3. Sections from the sows fed low-protein diets show reduced endometrial thickness and a marked reduction in the number and diameter of the glands. Histological 
sections from the PMSG/HCG-injected sows were similar in appearance to those from high-protein sows.

Failure of the sows fed low-protein diets to exhibit cyclic activity was apparently due to an insufficiency of gonadotrophin production and/or release. When injected with PMSG and HCG, they exhibited oestrus, produced ova and the weight of the reproductive tracts increased significantly.

The results of the two trials indicate that, although sows will tolerate a severe protein restriction for one gestation, the continuance of a low-protein $(5 \%)$ level for first-litter sows during lactation and after weaning markedly impairs their subsequent reproductive efficiency, as measured by incidence of oestrus, interval from weaning to oestrus and ovulation rate.

\section{REFERENCES}

Adams, C. R., Becker, D. E., Terrill, S. W., Norton, W. H. \& Jensen, A. H. (1960) Rate of ovulation and implantation in swine as affected by dietary protein. 7. Anim. Sci. 19, 1245.

Baker, D. H., BECKer, D. E., Jensen, A. H. \& Harmon, B. G. (1970) Reproductive performance and progeny development in swine as influenced by protein restriction during various portions of gestation. F. Anim. Sci. 31, 526.

BoAz, T. G. (1962) The significance of level of protein in the nutrition of the pregnant sow. Vet. Rec. 74, 1482.

DeGeeter, M.J., Hays, V. W., Kratzer, D. D. \& CRomwell, G. L. (1970) Reproductive and progeny performance of protein restricted gilts. F. Anim. Sci. 31, 199.

DeGeeter, M. J., Hays, V. W., Cromwell, G. L. \& Kratzer, D. D. (1970) Reproductive and progeny performance of protein restricted gilts. J. Anim. Sci. 31, 1020.

Frobish, L. T., SPEER, V. C. \& HAYs, V. W. (1966) Effect of protein and energy intake on reproductive performance of swine. F. Anim. Sci. 25, 729.

Holden, P. J., Lucas, E. W., Speer, V. C. \& Hays, V. W. (1968) Effect of protein level during pregnancy and lactation on reproductive performance of swine. $\mathcal{F}$. Anim. Sci. 27, 1587.

LuGas, E. W., SpeER, V. C. \& HAYs, V. W. (1966) Effect of protein intake on reproductive performance of sows. F. Anim. Sci. 25, 1250.

Pond, W. G., Strachen, D. N., Sinka, Y. N., Walker, E. F., Jr, Dunn, J. A. \& Barnes, R. H. (1969) Effect of protein deprivation of swine during all or part of gestation on birth weight, postnatal growth rate and nucleic acid content of brain and muscle of progeny. $\mathcal{F}$. Nutr. 99, 61. 